\title{
Research on Reform of County-level Administrative Law Enforcement in View of Law-based Government
}

\author{
Li Kun \\ School of Public Administration \\ Yunnan University of Finance and Economics \\ Kunming, China
}

\begin{abstract}
County-level administrative law enforcement includes the city administrative law enforcement of countylevel cities and rural administrative law enforcement of countryside areas, which is featured with comprehensiveness, orientation of rural policy, regional characteristics, etc. On the issues that the existing county-level administrative law enforcement system is not going very well, duty division is not clear, law enforcement efficiency is not high and so on, this thesis proposed that we should step up the construction of lawbased government and the reform of super-ministry system to promote the integration of county-level administrative law enforcement subjects, allocate law enforcement power reasonably and innovate more efficient ways to enforce the law.
\end{abstract}

Keywords-county-level government; administrative law enforcement reform; path choice

As a part of government functions transformation, reform of administrative law enforcement plays a critical role in administrative system reform. Administrative law enforcement system relates various respects such as lawexecutor, authority, content, procedure, way and supervision of law enforcement. The Central Committee of the Communist Party of China released "Decisions on a number of important issues in relation to comprehensively implementing governing the country by law". It says that the government is committed to promote comprehensive law enforcement to reduce the ranks of law enforcement types both in city and county level of government; The management of administrative law enforcement of city and county levels of government is to be improved and the leadership is to be unified and coordinated. City and countylevel administrative law enforcement is the specific embodiment of the whole administrative law enforcement system. However, there are still some problems in our country's administrative law enforcement system. For example law enforcement may be duplicate, repetitive and troublesome for the residents. The ultimate aim of promoting the reform of county-level administrative law enforcement is how to solve these problems and how to benefit the most people. The reform of administrative law enforcement is the inevitable choice of constructing lawbased government.

\section{AdMinistrative LAW ENFORCEMENT REFORM IS AN INEVITABLE CHOICE OF LAW-BASED GOVERNMENT CONSTRUCTION}

A. The County-level Administrative Law

Enforcement Reform is the Inevitable Result of the

Super-ministry Reform

Since 2013, the State Council launched the superministry reform to transform the government's administrative functions and optimize its organizations. The super-ministry reform is to make up super-large government department by reorganizing and combining government sectors. And these sectors are integrated with correlative departments according to their functions. The super-ministry aims to get a sector provide more kinds of services. This combination can help related affairs be dealt in only one sector, so that the administrative efficiency can be totally improved and the cost will be reduced. Since functional departments of county-level government are set up integrally and specifically, the government must carry forward the super-ministry reform by integrating sectors with similar functions and downsizing administrative organizations. And some malpractices like poly-execution, duty overlapped, barriers between different levels, inefficiency and difficulty for coordination in a same level, all of which must be eradicated. County-level administrative law enforcement is primarily decided by various administrative functional sectors, laws and regulations, departmental rules and administrative decisions. It aims to maintain normal social order. Its essence is to fulfill the corresponding government functions through law enforcement activities. As super-ministry reform bringing out the reform of county-level government functions and the relocation of government institutions, county-level administrative law enforcement system also needs to reform and reconstruct to keep up with the change of its functions. Therefore, to promote the county-level administrative law enforcement reform is the inevitable result and the realistic choice of the super-ministry system reform. 
B. County-level Administrative Law

Enforcement is the Critical Step to Strengthen the Lawbased Administration

The Third Plenary Session of the 18th Central Committee of the CPC made a "Decision on some major issues concerning comprehensively deepening the reform". This decision has made it clear that "to promote the construction rule China by law" is a strategic objective, and pointed out that "to build the rule of law in China, we must uphold the rule of law, governance and administration according to law together, and uphold the rule of law, lawbased government and law-based society." At the same time, China should take deepening reform of administrative law enforcement as its major objectives and tasks when practice rule by law.

The value of rule by law is on implementing it. The most important executive body of the legal system is administrative organization. Law enforcement is undertaken by the executive authorities as the most important daily activities. It is the main approach to implement laws and regulations, and manage the political, economic, social and cultural affairs by law. It also helps the government to achieve its functions. At present, $80 \%$ of the law and $90 \%$ of almost all local regulations and administrative rules are executed by the executive authorities. ${ }^{1}$ County-level administrative law enforcement is the foundation of our law enforcement system, which bears the primary law enforcement responsibilities and tasks. It should be said, the county-level administrative law enforcement is a major force in the entire national administrative law enforcement system. Its fundamental position in our government law enforcement system determines whether we can build clear responsibilities, code of conduct, effective supervision to ensure effective county-level administrative law enforcement system And it will be crucial for us to build law-based government and administration according to law.

\section{The SCOPE OF COUNTY-LEVEL ADMINISTRATIVE LAW ENFORCEMENT REFORM}

\section{A. The Connotation of County-level Administrative Law Enforcement}

Administrative law enforcement is a relatively rich and complex concept. In a broad sense, administrative law enforcement refers to the state administrative organs implement a given legal power and ways in accordance with the terms of reference and modalities. In the narrow sense, administrative law enforcement refers mainly to administrative penalties, supervision and administrative enforcement, while some scholars also believe that administrative approval also belongs to the scope of administrative law enforcement.

County-level law enforcement is a relatively comprehensive concept, which is based on the concept of a

\footnotetext{
${ }^{1}$ Yan Shuhong. Deepen the reform of administrative law enforcement system. Guangming Daily, Nov. $27^{\text {th }}, 2013,2^{\text {nd }}$ edition.
}

particular county-level administrative divisions for the proposed boundaries of time and space. At the same time, the county-level administrative law enforcement is the basis of the longitudinal part of the administrative law enforcement system. And it has most direct, significant and specific impact on citizens' interests. We believe that the county-level administrative law enforcement refers to administrative law enforcement agencies and law enforcement personnel to achieve administrative goals in the county administrative areas, according to the statutory powers and legal procedures, enforcement of laws, rules, regulations and executive orders higher levels of government. It directly practices power on specific person and certain administrative affairs some certain administrative services mainly like administrative penalties, administrative inspection, administrative supervision and administrative coercive measures. Thereby it will affect and change the relative rights and obligations to maintain external administrative acts related to public interests and social order.

County-level administrative law enforcement does not include that the administrative counterparts initiatively apply and the administrative sectors give benefits to the administrative counterparts including administrative licenses, confirmation and approval, etc. while not including abstract administrative behaviors which do not affect the specific counterpart like administrative decisions and commands. The breadth, complexity and scope of the particular county's economic and social activities determine the county administrative enforcement inclusive, comprehensive, agricultural policy, regional characteristics. It is an administrative law enforcement category with a particular spatial and temporal scales.

\section{B. The Scope of County-level Administrative Law Enforcement}

Determined by county social and economic structural characteristics of the county law enforcement, county-level administrative law enforcement covers not only the administrative law enforcement in urban areas, its scope is broader than the city's comprehensive law enforcement. County-level administrative law enforcement consists of two areas: First, county-level cities as the core of the city administrative law enforcement. Second, the vast rural areas as the main agricultural and rural law enforcement.

County-level city administrative law enforcement is within the scope of city-level administrative law enforcement. Throughout the reform process, administrative law enforcement of the city has gone through several stages including the departments administrative law enforcement, joint law enforcement, the relative concentration of administrative punishment as well as the city's comprehensive administrative enforcement. In 2015, the central government issued "Opinion on Advancing Urban Law Enforcement System Reform and Improved Urban Management", which regards "promote the comprehensive administrative enforcement" as a momentous mode of governance to improve urban management and advance the standards of urban management and the quality of its service. 
This guidance clearly defines the scope of responsibility of urban management including major municipal management, environmental management, traffic management, emergency management and implementation of urban planning and management. ${ }^{2}$ However, each urban management field relates to administrative penalties, administrative inspection, administrative supervision and administrative coercion law enforcement activities. Its specific range mainly includes the municipal construction(including the construction of public facilities, housing construction, etc.), urban environmental management, transport operation management and other fields. These fields are also present the main functions of the county level administrative law enforcement departments.

Another important field of county-level administrative law enforcement is law enforcement in the rural area. It mainly refers to the administrative law enforcement related to rural agriculture, areas that are closely related to agriculture, forestry, water conservancy, environmental protection and land. Rural administrative law enforcement is featured with "Agricultural policy" of rural properties, which determines its differences against urban administrative law enforcement. The main difference is that it is directly associated with agriculture, such as administrative checks, supervision and punishment of agriculture seeds, fertilizers, arable land, aquaculture, forests and. It can influence the stability of agriculture development more directly and specifically. There are some similar fields between the city and rural county administrative law enforcement, such as urban and rural housing construction, environmental protection, business management and other fields. Therefore, the county-level administrative law enforcement reform must be integrated with city and rural county administrative law enforcement. To build a comprehensive county administrative law enforcement system, it can coordinate and promote the integration of urban and rural county administrative law enforcement system.

\section{The Present Situation and Problems of COUNTY-LEVEl AdMINISTRATIVE LAW ENFORCEMENT IN CHINA}

\section{A. The Present Situation of County-level Administrative Law Enforcement in China}

Tracing back to the history of administrative law enforcement reform, the reform of administrative law enforcement in China began at "relatively centralized administrative punishment" pilot work after the " Administrative Penalty Law " in 1996. From 1997 to 2002, there are 23 provinces and 79 cities, including three autonomous regions---Beijing, Tianjin, Shanghai, and Guangdong province and Heilongjiang province. In 2002,

\footnotetext{
${ }^{2}$ The CPC Central Committee the State Council "Opinion on Advancing Urban Law Enforcement System Reform and Improved Urban Management, Dec. $24^{\text {th }}, 2015$. Xinhua online, http://news.xinhuanet.com/politics/2015/12/30/c 1117631143.h tm, December $30^{\text {th }}, 2015$.
}

having concluded the experience of this pilot work, the State Council promulgated the "decision on further promoting the relatively centralized administrative punishment work," ([2002] No. 17), authorized provinces, autonomous regions and municipalities that they can carry out a relatively concentrated administrative punishment work in the discretion of the administrative district. With the pilot project spreading across the board, the administrative law enforcement reform constantly enrich the connotation of development and implementation of comprehensive administrative enforcement, which is gradually being put on the agenda of government reform law. In the same year, the State Council forwarded " view on the rectification of administrative law enforcement team, the implementation of comprehensive administrative enforcement pilot ", deciding to start pilot in Guangdong and Chongqing. Other provinces, cities and districts were selected to 1-2 prefecture or county mainly related to the fields of urban management, agricultural management, environmental resource management, cultural market management, transportation management. Comprehensive law enforcement reform officially started. Throughout the national comprehensive reform pilots of administrative law enforcement, it mainly included city management, cultural market, agriculture, resources, environment, transportation, and food and health fields.

For a long time, under the economic and social impact of traditional rural and urban "dual" structure, the county administrative law enforcement has not received the attention it deserves. County-level administrative enforcement system reform has subordinated city administrative law enforcement for a long time. Countylevel city is mainly focused on the relatively centralized administrative punishment pilots and comprehensive administrative reform and reform of law enforcement in all areas. From the problems reflected by the reform, countylevel administrative law enforcement is similar to the city administrative law enforcement. There is also the authority weakened longitudinal and transverse dispersion of administrative law enforcement, law enforcement agencies fragmentation, low efficiency of law enforcement, simple and extensive administrative enforcement methods. In recent years, some local city and county governments run a useful exploration in deepening the reform of administrative law enforcement, such as integrating law enforcement body, relative concentrating law enforcement powers, implementing joint law enforcement departments, promoting comprehensive law enforcement, establishing system of law enforcement responsibility, innovating law enforcement methods. Modifications in the reform of rural county administrative law enforcement, there are comprehensive administrative enforcement reform. Since 1999, pilot on comprehensive law enforcement being launched, the original "seven eight stations----overlapped sectors were set in prefectures" had decentralized punishment exercise, which in 2005 has been centralized. At that time, the country had 30 provinces (both autonomous regions and municipalities), 1,539 counties (local cities) carrying out rural comprehensive cooperative enforcement and setting up a universal comprehensive agricultural law 
enforcement agencies. ${ }^{3}$ The reform of administrative law enforcement had a positive meaning to promoting the rule of law of county-level administrative law enforcement reform, standardization of content, standardization of enforcement procedures and scientificaction of enforcement instruments.

\section{B. $\quad$ The Present Problems of County-level} Administrative Law Enforcement in China

1) Divisions of administrative law enforcement duties is not clear, boundaries of law enforcement functions and management functions are fuzzy

When administrative law enforcement subject implement laws and regulations, the implementation of administrative enforcement is outside the legal system of the administrative act, which is also an important way to fulfill administrative functions. After relatively centralized administrative punishment reform pilots, county government departments have become the comprehensive administrative law enforcement departments related to main fields like agriculture, transportation, food safety and health. And to assume a plurality of original features within the executive departments different functions or administrative subject, the reform merged the functions of them into the newly established administrative law enforcement departments. However, during the process of segregation of duties, due to the existing institutional hinder and sectors' interests bound, division of power of county-level administrative law enforcement between the executive parts are not clear, especially for some administrative enforcement power divisions mainly like administrative supervision, administrative prosecution, technical inspection. And with implementing super-ministry system reform, county government departments, agencies and their functions are facing a new round of integration and restructuring. Departments functions are overlapped between law enforcement sectors and administrative sectors. Law enforcement functions residing administrative functions are quite prominent. And some department rules have no clear boundaries between administrative management functions and law enforcement functions. These all lead to the management activities of the original administrative departments and the law enforcement activities cross and conflict.

2) Integrations among law enforcement agencies have not been done enough so that horizontal coordination is difficult

Our county government agency system is organized relatively completely, which generally corresponds to provincial and municipal departments. This kind of organization model can effectively implement the higher level policies, but it can also lead to division of functions of government departments and county institutional settings. Some of the government departments with similar functions are lack of effective integration. In the field of

\footnotetext{
${ }^{3}$ Gao Xiaoping, Shen Ronghua. Promoting the reform of Comprehensive law enforcement system: effect, problems and resolutions [J]. Chinese Public Administration, No.5, 2012.
}

administrative law enforcement, part of the economic and social management affairs are allocated to different departments, such as the main law enforcement subject of rural water sources is managed by environmental protection departments, and agricultural water managed by the agricultural sector, food and drug safety in production managed by the food and drug supervision, while food sales run by administrative department for industry regulation.

It is bound to make the administrative difficulties that different segments of the same matters of administrative law enforcement subject is divided to different regulatory departments. What is worse, there still exists the lack of regulatory convergence and cooperation between these departments, which makes the process's coordination difficulty. And it can finally leads to "power vacuum" of the administrative law enforcement that is called the "dozens of top hats can not control a little hat". At the same time, the fuzzy boundaries between functions of the administrative and law enforcement also make coordination of administrative law enforcement departments and administrative management departments difficult. This deep rooted institutional conflict is a major obstacle to deepening the reform of administrative law enforcement.

3) Procedures of administrative law enforcement are not standardized, ways of law enforcement are not scientific

Administrative law enforcement activities belong to external administrative behaviors which mean the administrative subject inspects, supervises or even punishes whether administrative counterpart abides by relevant laws and regulations. Over the years, many county administrative law enforcement agencies and law enforcement personnel lack of awareness of the rule of law when engaged in administrative law enforcement activities, especially lack of awareness of proceedings. In addition that citizens of the county lack of awareness of their rights, all led to administrative law enforcement agencies lack of a comprehensive and accurate understanding of the law enforcement subject legality, applicable laws, enforcement procedures and enforcement tools when implementing administrative law enforcement activities. At present, there still exists misconducts and other illegal practices in varying degrees during the county-level administrative enforcement process such as the main law enforcement subject disqualification, violation of procedure and inappropriate applicable laws. Especially simple and extensive ways of law enforcement impact the authority of the county administrative law enforcement activities, which is brought out by the serious deficiency and random law enforcement of part of law enforcement leaders and staff's legal awareness and legal literacy. So a number of administrative law enforcement activities are criticized by public people. 


\section{Main Policies for Promoting County-LEVEL ADMINISTRATIVE LAW ENFORCEMENT}

A. To develop county's economy and promote the reform of government functions, fields and power allocation of county-level administrative law enforcement should be clarified

Government functions is the logical starting point of the operation of the executive power, but also the main basis for the implementation of administrative law enforcement. Currently, we steadily implement the reform pilot of "county directly under the provincial government" and the super-ministry system reform of the administrative system, which will help promote the transformation of county government's functions, optimize resource allocation. To ensure that the transformation of government functions can promote economic development, strengthen market supervision, intensify social management and improve public service, thus the county government administration and administrative capacity levels can be gradually improved. County government fulfills its administrative functions mainly through the implementation of laws and regulation. Therefore, when implementing the reform of county-level administrative law enforcement, its critical aim is to transform the government functions so that some main areas and power allocation of the county administrative law enforcement can be to further clarified. First, scopes and boundaries of the administrative law enforcement should be divided scientifically and clearly, particularly the management functions of government executive department and the law enforcement functions of law enforcement departments should be defined clearly. So the problems of functional overlap and conflicts can be resolved between the administrative activities and enforcement activities. Second, the administrative enforcement responsibilities should be further integrated, the coordination and cooperation between different law enforcement agencies should be strengthened, in particular, convergence of law enforcement activities should be strengthened effectively in relevant field, such as industry and commerce administrative law enforcement, law enforcement on food and drug safety, environmental protection and agricultural administrative law enforcement, therefore administrative law enforcement process can achieve seamless docking.

\section{B. $\quad$ Taking Super-ministry System Reform as} an Opportunity to Promote the Integration of County Administrative Law Enforcement Subject

In recent years, the county administrative law enforcement reform has gone through the joint law enforcement, the relatively concentrated punishment of administration, administrative law enforcement responsibility, comprehensive administrative and law enforcement reform, which has played an important role in making county administrative law enforcement more scientific and, institutionalized and standardized. With further promoting the super-ministry reform, the administrative functions of county government is facing a new round of re-relocation. And to transform functions, the administrative departments reforms are being carried out steadily. Correspondingly, the law executive power of the county-level administrative law enforcement are appropriately adjusted and re-relocated along with transformation of government functions and institutional reforms. In a result, comprehensive administrative law enforcement bureau have set up in various fields, such as comprehensive administrative enforcement bureau of following fields---- agriculture, transportation and the cultural market, etc. These are new requirements proposed to administrative law enforcement activities by transformation of government functions and restructuring. It is also the inevitable choice if administrative law enforcement activities actively adapt to the super-ministry system reform. In the future, we should implement a comprehensive county administrative law enforcement as the starting point to promote the further integration of the county administrative law enforcement subject. And law enforcement authority and the responsibility of the county administrative law enforcement subject should be unified. In particular, it is important to make the appropriate administrative inspection, administrative supervision, administrative enforcement and other law enforcement activities as the specific responsibility under the appropriate law enforcement subject, not just placed under administrative punishment.

In addition, professionally technical administrative law enforcement activities should also be carried out under further improving the conditions for the transfer of software and hardware of law enforcement subject. And the subject, basis and standards of administrative law enforcement should be more standardized and reasonable.

\section{Changing the Core Concept of}

Administrative Law Enforcement, Promoting the

Innovationof Ways and Means of Administrative Law

Enforcement

With modern management concepts gradually getting into the public administrative practices and a general increase in awareness of civil rights, the construction of the rule of law government, responsible government, serviceoriented government has become an important goal of the new era when promoting governance model reform. Function of county government departments is gradually transformed into maintaining market order, strengthening social management and public service delivery, and establishing a good public service concept has become an inevitable requirement of administrative sectors and their staff. County administrative law enforcement activities is essentially administrative subject performing its functions and tasks. And it also requires law enforcement subject to establish the concept of public service in the implementation of laws and regulations, and service awareness must be enhanced, not only in the implementation of administrative examination and administrative oversight and also in the course of the implementation of administrative penalties. In the practice of administrative penalties, punishment should be combined with education, at least punishment is a means not its goal. We must resolutely put an end to administrative 
penalties, especially fines as a sector assessment indicators. We should prohibit disguised forms and means to link fines and sector performance, and strictly enforce the separation of the penalty payment system. At the same time, we should take innovative ways to carry out law enforcement activities in the process of law enforcement, including administrative guidance, administrative contract.

\section{CONCLUSION}

In summary, promoting county-level administrative law enforcement system reform is a necessary requirement to improve the governance structure and build serviceoriented government, the rule of law government. Through analyzing and summarizing the situation and problems existing in connotation, function, present law enforcement situation of law enforcement, this thesis analyzed the current difficulties faced by the county administrative enforcement system reform, put forward that we should further rationalize the county government management system, integrate administrative law enforcement power, optimize administrative law enforcement legal guarantees, a clear the relationship between rights and responsibilities, strengthen horizontal coordination between administrative law enforcement departments, standardize administrative law enforcement activities, innovate law enforcement ways and means, improve the efficiency and level of law enforcement.

\section{REFERENCES}

[1] Jiang Ming'an. Research on administrative law enforcement [M]. Beijing: Beijing University Press, 2004.

[2] Wang Jingbo. City management and administrative law enforcement[M]. Beijing: Research Press, 2011.

[3] Zheng Caifa . Countermeasures and proposal to deepening the reform of county-level administrative law enforcement [J]. Chinese Public Administration, 2015, the 10th edition. 